\title{
Climate and land-use changes affecting river sediment and brown trout in alpine countries-a review
}

\author{
Karin Scheurer • Christine Alewell • \\ Dominik Bänninger • Patricia Burkhardt-Holm
}

Received: 15 June 2008 / Accepted: 7 November 2008 / Published online: 2 December 2008

(C) Springer-Verlag 2008

\begin{abstract}
Background, aim, and scope Catch decline of freshwater fish has been recorded in several countries. Among the possible causes, habitat change is discussed. This article focuses on potentially increased levels of fine sediments going to rivers and their effects on gravel-spawning brown trout. Indications of increased erosion rates are evident from land-use change in agriculture, changes in forest management practices, and from climate change. The latter induces an increase in air and river water temperatures, reduction in permafrost, changes in snow dynamics and an increase in heavy rain events. As a result, an increase in river sediment is likely. Suspended sediment may affect fish health and behaviour directly. Furthermore, sediment loads may clog gravel beds impeding fish such as brown trout from spawning and reducing recruitment rates. To assess the potential impact on fine sediments, knowledge of brown trout reproductive needs and the effects of sediment on brown trout health were evaluated.

Approach We critically reviewed the literature and included results from ongoing studies to answer the following questions, focusing on recent decades and rivers in alpine countries.

- Have climate change and land-use change increased erosion and sediment loads in rivers?

- Do we have indications of an increase in riverbed clogging?
\end{abstract}

K. Scheurer $\cdot$ P. Burkhardt-Holm $(\square)$

Man-Society-Environment MGU, University of Basel,

Vesalgasse 1,

4051 Basel, Switzerland

e-mail: patricia.holm@unibas.ch

C. Alewell • D. Bänninger

Institute of Environmental Geosciences, University of Basel,

Bernoullistrasse 30,

4056 Basel, Switzerland
- Are there indications of direct or indirect effects on brown trout from increased suspended sediment concentrations in rivers or from an increase in riverbed clogging?

Results Rising air temperatures have led to more intensive precipitation in winter months, earlier snow melt in spring, and rising snow lines and hence to increased erosion. Intensification of land use has supported erosion in lowland and prealpine areas in the second half of the twentieth century. In the Alps, however, reforestation of abandoned land at high altitudes might reduce the erosion risk while intensification on the lower, more easily accessible slopes increases erosion risk. Data from laboratory experiments show that suspended sediments affect the health and behaviour of fish when available in high amounts. Point measurements in large rivers indicate no common lethal threat and suspended sediment is rarely measured continuously in small rivers. However, effects on fish can be expected under environmentally relevant conditions. River bed clogging impairs the reproductive performance of gravel-spawning fish.

Discussion Overall, higher erosion and increased levels of fine sediment going into rivers are expected in future. Additionally, sediment loads in rivers are suspected to have considerably impaired gravel bed structure and brown trout spawning is impeded. Timing of discharge is put forward and is now more likely to affect brown trout spawning than in previous decades.

Conclusions Reports on riverbed clogging from changes in erosion and fine sediment deposition patterns, caused by climate change and land-use change are rare. This review identifies both a risk of increases in climate erosive forces and fine sediment loads in rivers of alpine countries. Increased river discharge and sediment loads in winter and early spring could be especially harmful for brown trout reproduction and development of young life stages. 
Recently published studies indicate a decline in trout reproduction from riverbed clogging in many rivers in lowlands and alpine regions. However, the multitude of factors in natural complex ecosystems makes it difficult to address a single causative factor.

Recommendations and perspectives Further investigations into the consequences of climate change and land-use change on river systems are needed. Small rivers, of high importance for the recruitment of gravel-spawning fish, are often neglected. Studies on river bed clogging are rare and the few existing studies are not comparable. Thus, there is a strong need for the development of methods to assess sediment input and river bed clogging. As well, studies on the effects to fish from suspended sediments and consequences of gravel beds clogging under natural conditions are urgently needed.

Keywords Alpine region - Agriculture - Brown trout . Climate change $\cdot$ Clogging erosion $\cdot$ Fish health $\cdot$ Global change · Gravel-spawning · Hydrology · Land-use change . Precipitation $\cdot$ Reproduction $\cdot$ Rivers $\cdot$ Salmonids $\cdot$ Salmo trutta $\cdot$ Suspended sediment

\section{Background, aim, and scope}

Freshwater fish catches have been declining dramatically in the last decades in many countries (EIFAC 2002). In Switzerland, the reported trout catch decreased in $85 \%$ of the investigated rivers. In some rivers, catches have been declining by up to $10 \%$ per year since the early 1980 s (Fischnetz 2004). A decline in fish health was also observed with this trend and together have been the reason to launch a nationwide interdisciplinary research project called 'Fischnetz' in 1998 (Burkhardt-Holm et al. 2002; Fischnetz 2004). Three main causes for the decrease in brown trout catches were identified: (1) fisheries management; (2) PKD (proliferative kidney disease); and (3) poor habitat morphology and water quality (Burkhardt-Holm et al. 2005). Among the poor habitat morphology, the hypothesis of increased soil erosion and subsequent sediments going into rivers was discussed. However, particularly due to insufficient data availability, the linkage to riverbed clogging (reduction in riverbed interstitial flow from sediment deposition) and direct or indirect impairment on fish health by suspended sediments could not be evaluated (Fischnetz 2004).

One potential cause of increased erosion and sediment loads in rivers could be increased temperatures, altered precipitation patterns (strength, timing and altitude), changes in snow cover and seasonal snow melting caused by climate change (IPCC 2007; Fuhrer et al. 2006; Beniston 2006). These may have led to increased river runoff, especially in winter and in spring, and altered seasonal and regional sediment load and riverbed clogging patterns.
A second driver of potentially increased erosion rates is change in land use, which affects natural habitats and stream morphology significantly. The combination of more intensive rainfall and changes in land use have generally led to increased erosion over the last decades (FAL 2001; Gentile and Werner 2004). In addition, rivers have been modified in the twentieth century for flood protection, bed stabilization and hydropower dams and have influenced flow velocity and gravel movement: these factors together have supported riverbed clogging.

The purpose of this review is to study changes in erosion and levels of fine sediment (sediments with a diameter $<2 \mathrm{~mm}$ ) going into alpine rivers from land use and climate change and assess the effects on brown trout reproductive performance and health.

\section{Approach}

We aim to answer the following questions with a focus on recent decades and the alpine region

- Have climate change and land-use change increased erosion and sediment loads in rivers?

- Do we have indications of an increase in riverbed clogging?

- Are there indications of direct or indirect effects on brown trout from increased suspended sediment concentrations in rivers?

- Are there indications of direct or indirect effects on brown trout from an increase in riverbed clogging?

\section{Results and discussion}

\subsection{Climate change and expected effects on soil erosion}

\subsubsection{Consequences of changes in air temperature}

Recent studies have shown that air temperature in the alpine regions is changing more rapidly than in other regions of the northern hemisphere and the global average (Lebensministerium 2003; Beniston 2006; Hari et al. 2006). From data analyses of twelve stations in Switzerland in the period 1864-2000, Begert et al. (2005) found a rise in temperature by $1.1^{\circ} \mathrm{C}$ and $0.6^{\circ} \mathrm{C}$ per century in northern and southern side of the Alps, respectively, (Table 1) and the warming occurred mainly during autumn and winter months. However, more recently (1978-2002), changes in air temperatures occurred in spring and summer at lower altitude stations ( $<700 \mathrm{~m}$ a.s.1.; Hari et al. 2006). Rising air temperature is reflected in coherent rise in water temperatures (up to $+1.1^{\circ} \mathrm{C}$ ) in streams both in the lowlands and in 
Table 1 Change in climate parameters in alpine countries (e.g. Switzerland $(\mathrm{CH})$ for river discharge) in different seasons (Winter: Dec/Jan/Feb, Spring: Mar/Apr/Mai, Summer: Jun/Jul/Aug, Autumn: Sep/Oct/Nov)

\begin{tabular}{|c|c|c|c|c|c|c|c|c|c|c|c|c|c|c|c|c|}
\hline & \multicolumn{4}{|l|}{ Winter } & \multicolumn{4}{|l|}{ Spring } & \multicolumn{4}{|l|}{ Summer } & \multicolumn{4}{|l|}{ Autumn } \\
\hline & $\mathrm{dT}\left[{ }^{\circ} \mathrm{C}\right]^{\mathrm{a}}$ & $\mathrm{P}^{\mathrm{b}}$ & $\mathrm{S}^{\mathrm{c}}$ & $\mathrm{D}^{\mathrm{d}}$ & $\mathrm{dT}\left[{ }^{\circ} \mathrm{C}\right]^{\mathrm{a}}$ & $\mathrm{P}^{\mathrm{b}}$ & $\mathrm{S}^{\mathrm{c}}$ & $D^{d}$ & $\mathrm{dT}\left[{ }^{\circ} \mathrm{C}\right]^{\mathrm{a}}$ & $\mathrm{P}^{\mathrm{b}}$ & $\mathrm{S}^{\mathrm{c}}$ & $D^{d}$ & $\mathrm{dT}\left[{ }^{\circ} \mathrm{C}\right]^{\mathrm{a}}$ & $\mathrm{P}^{\mathrm{d}}$ & $\mathrm{S}^{\mathrm{c}}$ & $D^{d}$ \\
\hline $\mathrm{CH}$ & & nd & nd & $\uparrow$ & & nd & nd & $\uparrow$ & & nd & nd & $\downarrow$ & & nd & nd & $\uparrow$ \\
\hline North & $+1.0-1.5$ & $\uparrow \uparrow$ & $\downarrow$ & nd & $+0.8-1.0$ & $\boldsymbol{\uparrow} \uparrow^{\mathrm{e}}$ & $\downarrow$ & nd & $+0.7-1.0$ & $\downarrow \uparrow$ & nd & nd & $+1.0-1.3$ & $\boldsymbol{\downarrow} \uparrow$ & nd & nd \\
\hline Alps & $+1.2-1.6$ & $\uparrow$ & $\uparrow$ & nd & $+0.8-1.0$ & nd & nd & nd & $+0.6-1.0$ & nd & nd & nd & $+1.2-1.3$ & nd & nd & nd \\
\hline South & $+0.6-0.9$ & $\downarrow \downarrow$ & $\downarrow$ & nd & $+0.4-0.7$ & $\downarrow \uparrow$ & $\downarrow$ & nd & - & $\downarrow$ & nd & nd & $+0.7-0.8$ & $\boldsymbol{\downarrow} \uparrow$ & nd & nd \\
\hline
\end{tabular}

Change in Temperature in ${ }^{\circ} \mathrm{C}$ in the period $1864-2000$; increase (amount $\uparrow$ and intensity $\uparrow$ ) or decrease (amount $\downarrow$ and intensity $\downarrow$ ) in precipitation (P) in the periods 1807-2003 and 1901-2000, respectively; change in snow (S) depths (increase $\uparrow$, decrease $\downarrow$ ); change in river discharge (D; increase $\uparrow$, decrease $\downarrow$ )

${ }^{\text {a }}$ Begert et al. 2005

${ }^{\mathrm{b}}$ Brunetti et al. 2006 and Schmidli and Frei 2005

${ }^{\mathrm{c}}$ Beniston 2006

${ }^{\mathrm{d}}$ Birsan et al. 2005

${ }^{\mathrm{e}}$ Negative trend in recent years

the foothills of the Alps, but the changes are less obvious in alpine streams influenced by glaciers and/or hydropower stations (Hari et al. 2006; Matulla et al. 2007). Rising water temperature has shifted the thermal habitat for fish communities upwards up to $130 \mathrm{~m}$ (Hari et al. 2006; Matulla et al. 2007) and might affect fish health and reproduction (see discussion below).

While temperature will have no direct effect on river sediment loads, indirect effects can be expected from changed precipitation patterns, a decline in permafrost, snow melting and rising snow lines with associated potential increases in soil erosion.

\subsubsection{Changes in snow dynamics}

Rising air temperature and especially the increasing number of days with air temperatures above zero influence the occurrence of snowfall and time of snowmelt (Birsan et al. 2005), resulting in a rising snow line. Changes in snowmelt are considered to be mainly critical for altitudes between 500-800 (in winter) and 1,000-1,500 m a.s.l. (in spring; Wielke et al. 2004). Snow depths decreased in the late 1980 s and 1990s at low elevations $(<1,000-1,300 \mathrm{~m}$ a.s.l. in Jan-Feb; Laternser and Schneebeli 2003; Beniston 2006), but increased at high elevations $(>2,000 \mathrm{~m}$ a.s.l.; Beniston 2006). At the same time snow melting is reported to occur earlier in spring due to rising temperatures but with no obvious shift of snow accumulation in autumn (Laternser and Schneebeli 2003).

With the projection of further warming, the duration of snow cover is predicted to be shortened by more than 100 days with earlier snowmelt in spring (Jasper et al. 2004; Beniston 2006; Horton et al. 2006). A permanent snow cover in winter protects the soil from freezing, which is important for snowmelt infiltration and runoff, respectively (Stähli et al. 2001; Bayard et al. 2005). Thus, higher levels of rainfall and changes in freezing/thawing cycles can be expected to increase soil erosion and mass movement because of sparse or no vegetation cover at low elevations in winter and in early spring.

\subsubsection{Effects of changes in precipitation patterns}

The changes in precipitation patterns are different on the northern and the southern part of the alpine rim. While a significant negative trend for total annual precipitation over the last two centuries in the southern part of the Alps has been shown, the average trend was positive for the northern alpine region, particularly in winter and spring (Brunetti et al. 2006). An increase in amount and duration of torrential rain events, especially in winter and autumn months, during the last three to five decades has been demonstrated mainly for the northern alpine region while there is a slight positive, nonsignificant trend for the southern parts (Schmidli and Frei 2005; Fuhrer et al. 2006; Diodato and Mariani 2007). In the south, these extreme events alternate with increasing dry periods in autumn and spring (Schmidli and Frei 2005). In the north, the increase in precipitation in winter is also caused by extended long rain events (Schmidli and Frei 2005).

Torrential rain is widely believed to considerably contribute to sediment erosion (Summer 1989; Acornley and Sear 1999; Fraser et al. 1999; Descroix and Gautier 2002). Additionally, both droughts followed by heavy rain events and long consecutive rain events on already saturated soil can trigger erosion; the latter at an even higher extent than single day heavy rainfall events (Prasuhn 2003).

\subsubsection{Trends in fluvial hydrology}

Many studies pointed to the sensitivity of the alpine hydrological system to climate change (Weingartner et al. 2003; Jasper et al. 2004; Birsan et al. 2005; Horton et al. 
2006). A comprehensive trend analysis of the runoff regimes of 48 undisturbed catchment areas in Switzerland showed that the annual runoff increased in the last century (Table 1; Birsan et al. 2005). This was mainly due to a higher discharge in winter (mainly high flows), but also increased runoff for autumn and spring (moderate and low flows) since 1960. In another study, Santschi (2003) analyzed specifically the winter discharge in 41 river basins with respect to gravel bed movements and destruction of the upper layer of the riverbed. For alpine rivers and rivers south of the Alps, a critical increase in winter discharge was not evident with the available data (Santschi 2003). In the Swiss Plateau and the Jura, however, Santschi (2003) found an increase of high flows in winter for $35 \%$ of the rivers after 1960. These trends of increased winter discharge are suspected to lead to downstream sediment transport and scouring of riverbed and therefore are assumed to disturb fish reproduction. With the expected increase in temperature, some studies predict an advance of the peak flows in spring by $0.5-2$ month/century for the north side of the Alps and up to 1 month/century on the south side of the Alps (Jasper et al. 2004; Horton et al. 2006). However, the projected runoff peaks will be substantially lower (20-50\%) than the present peak flows (Jasper et al. 2004).

\subsection{Effects of land-use change on soil erosion}

Soil erosion is strongly influenced by human activity and land use. Since the late nineteenth century the forested area is increasing because reforestation was promoted for flood protection and erosion control (Table 2; RitzmannBlickenstorfer 1996; Bundesamt für Statistik 2001; Descroix and Gautier 2002; Piégay et al. 2004). Erosion rates in undisturbed forests are generally low. With increasing areas of forest a decrease in erosion was reported in different catchments in the Southern French Alps (Piégay et al. 2004; Liébault et al. 2005).

In recent decades, wooded area is still increasing mainly in the alpine and sub-alpine region due to the abandonment of alpine meadows (Bundesamt für Statistik 2001; Tasser and Tappeiner 2002; Krausmann et al. 2003; Piégay et al. 2004). These abandoned sites are mainly found in steep and remote areas (Bundesamt für Statistik 2001; Tasser and Tappeiner

Table 2 Relative change (\%) in landuse in Switzerland between the years 1979/85 and 1992/97 (Bundesamt für Statistik 2001)

\begin{tabular}{llll}
\hline & $\begin{array}{l}\text { Forest } \\
\text { areas }\end{array}$ & $\begin{array}{l}\text { Agricultural } \\
\text { areas }\end{array}$ & $\begin{array}{l}\text { Urban areas/ } \\
\text { settlements }\end{array}$ \\
\hline Jura/Central Plain & $+0.2-0.3$ & $-1.9-3.0$ & $+11.9-14.5$ \\
North Flank of the Alps & +1.7 & -2.2 & +14.9 \\
Central Alps & $+2.3-4.5$ & $-2.8-6.0$ & $+12.8-21.8$ \\
South Flank of the Alps & +2.7 & -10 & +13.8 \\
\hline
\end{tabular}

2002; Verbunt et al. 2005). Abandoned sites are, however, only slowly being reclaimed by forests. Several authors concluded that abandoned land is significantly more susceptible to erosion than managed meadows and pastures because managed pastures create small terraces and hence increase surface roughness and reduce soil erosion processes such as snow gliding (Johannes 1995; Tasser et al. 2003; Hiltbrunner et al. 2005). While Tasser et al. (2003) postulated that abandoned areas covered with shrubs or bushes appear to be more prone to suffer from landslides, Meusburger and Alewell (2008) found that abandoned areas being invaded by shrubs were more stable and had lower land slide densities than surrounding grasslands.

Between 1950 (predominantly from 1970) and 1990, the absolute farming area decreased. However during the same time, the arable land increased in some areas (mainly in prealpine and lowland region, e.g. in Switzerland by $23 \%$ ) but decreased in other areas (in alpine regions; on average in Austria by 14\%; Summer et al. 1996; Krausmann et al. 2003; Fischnetz 2004). The decrease in farming area caused an intensification of land use of the remaining farmland and therefore an increase in soil erosion risk enhanced by an increasing use of agricultural machinery. The increased cultivation of maize, sugar beet and wheat further intensified the risk of soil erosion (Summer et al. 1996; Fischnetz 2004).

In Switzerland, arable land and erosion sensitive crop areas are constant or have been slightly decreasing since the early 1990s, which is, together with improved agricultural practices, reflected in a steady decrease in the erosion risk (FAL 2001; Prasuhn 2003; Bundesamt für Landwirtschaft 2006). However, with improved crop management and soil cultivation in agricultural areas the erosion risk could be reduced mainly in summer but not in winter when protective (continuous) vegetation cover is naturally limited (Prasuhn 2003). In addition, a decrease of buffer strips along rivers due to an intensification of agriculture is suspected to have increased fine sediment loads in rivers.

\subsection{Effects of land-use and climate change on sediment yields in rivers}

Long-term trends in sediment yields have been mainly evaluated for larger Alpine rivers. The sediment yield in the Danube catchment has increased by $30-50 \%$ in the period 1950-1980 and to some degree in the river Lech after 1965 (Summer et al. 1994; Walling 1997). This trend is assumed to be caused by changed agricultural management and changed precipitation patterns, respectively. Looking at combined future climate and land-use change scenarios Asselman et al. (2003) calculated an increase in the future annual sediment supply of $250 \%$ for the alpine Rhine catchment. Decreasing trends were reported in areas of reforestation in the French Alps (Descroix and Gautier 
2002; Piégay et al. 2004; Liébault et al. 2005) or beneath hydropower plants (Habersack 1996; Weiss 1996; Walling 1997). Increasing trends in suspended sediment concentrations for peak flows have also been documented in some rivers (e.g. in the Danube by a factor up to 2; Summer et al. 1994), whereas in many cases no clear trend could be found (Zobrist et al. 2004). Higher sediment discharges are usually related to high flows during snowmelt or heavy rainfall in spring, summer and autumn (Lenzi et al. 2003; Margreth 2006; Asselman et al. 2003). Thus, the greatest transport of fine sediments within the stream occurs in relatively short time periods (Summer et al. 1994; Hamm et al. 1996). Suspended sediment may only reflect the smallest fraction of fine sediments (silt and clay) transported downstream. (Heywood and Walling 2007) concluded that the majority of sediment accumulating in the riverbed is transported downstream with the fine-grained bed load.

Reservoir hydropower plants and other dam construction affect the magnitude and timing of hydrological regime and downstream sediment transport substantially, which often results in gravel deficiency downstream (Habersack 1996; Weiss 1996; Walling 1997; Beyer Portner 1998). In Swiss rivers, most hydropower stations were constructed between the years 1930-1970 (www.swissdams.ch). In cases of deposition of fine sediment or a lack of regular gravel movement, riverbed clogging might occur. In Switzerland and other European countries, observations of fish experts and anglers have indicated a general increase in riverbed clogging (Walling et al. 2003; Bolliet et al. 2005; Fischnetz 2004). Construction work for flood protection and riverbed stabilisation up to the 1980s has contributed substantially to riverbed clogging. Riverbed clogging was observed in many streams downstream of hydropower plants (Baumann and Klaus 2003).

Seasonal changes in river discharge due to changed precipitation patterns and earlier snowmelt may have changed the timing of the sediment transport downstream. Sediment transport downstream alternating with sediment deposition on gravel beds can now be expected to occur also in winter and earlier in spring and hence affecting trout spawning and incubation.

3.4 Effects of temperature increase, high discharge, suspended solids and riverbed clogging on brown trout (Salmo trutta)

\subsubsection{Effect of changes in temperatures and high discharge on spawning and embryo development of brown trout}

In the alpine regions, reproduction season of brown trout is during autumn and winter months with a spawning season from October to January (Zaugg et al. 2003). Growth of embryos is dependent on temperature but differences between populations seems to be small (Crisp 2000). Depending on altitude and temperature, fry emerge from gravel beds in April and May $(<700 \mathrm{~m}$ a.s.1.: April, $>1,200 \mathrm{~m}$ a.s.l.: May; Hari et al. 2006). Since the rise in temperature due to climate change occurred particularly in autumn and winter seasons, it directly influences reproduction and egg development. Accordingly, the emergence of brown trout fry from the gravel beds is predicted to have advanced by $2.8-5.6$ days per decade in alpine rivers (Hari et al. 2006).

The timing of high discharges is especially critical for egg and fry development. Naturally, discharge is low in winter. With climate change, an increased discharge during winter, spring and autumn was observed (Birsan et al. 2005) and with the predicted advance of peak flows in spring (Jasper et al. 2004; Horton et al. 2006) the timing could overlap fry emergence. Fry, around the time of emergence, is considered to be the live stage most sensitive to high floods (Jensen and Johnsen 1999; Cattanéo et al. 2002; Tetzlaff et al. 2005) whereas egg scouring is thought to occur only with extreme events (Cattanéo et al. 2002). However, only a slight increase in discharge could result in significant egg damage (Montgomery et al. 1996) and high discharges during incubation time and emergence was found to be inversely related to year-class-strength of brown trout (DeVries 1997; Spina 2001; Cattanéo et al. 2002). As scouring is, besides discharge, dependent on gravel size and bedform roughness (Montgomery et al. 1996; Lapointe et al. 2000) critical discharge is different for each stream. In $35 \%$ of the investigated river basins in the Swiss Plateau and Jura, an increase in winter discharge and frequency of extreme events are estimated to have occurred and could have led to critical gravel movement and hence to egg scouring (Santschi 2003). However, to date, no study exists, which investigates the implications of both the advanced river peak-flow and the advanced fry emergence in the alpine region.

\subsubsection{Impact of suspended sediment loads on behaviour, health and survival of brown trout}

With high discharges, high loads of fine sediment are usually transported downstream. These sediments are suspended in the water column above a certain water velocity and deposit to the river bottom when velocity decreases. With prolonged exposure time or increased concentrations, suspended sediment with values above $90 \mathrm{mg} \mathrm{l}^{-1}$ can affect fish directly with increasing risk of mortality or damage of gill or skin epithelia (Fig. 1; reviewed data in Alabaster and Lloyd 1980; Newcombe and MacDonald 1991; Berry et al. 2003). Physical damage of gill and skin epithelia include thickening of gill lamellae, clogging of gills, hyperplasis and necrosis - all of which can have detrimental effects on the individual fish (Berry et 
Fig. 1 Concentrations of suspended sediments and related effects on trouts in dependence of exposure time. Area below dotted straight line is measured (cross symbol) and estimated concentrations in Swiss rivers (unpublished data LHG and NADUF). Below straight line, no LC (lethal concentrations) was found (Herbert et al. 1961; Alabaster and Lloyd 1980; Newcombe and MacDonald 1991; Newcombe and Jensen 1996; Berry et al. 2003)

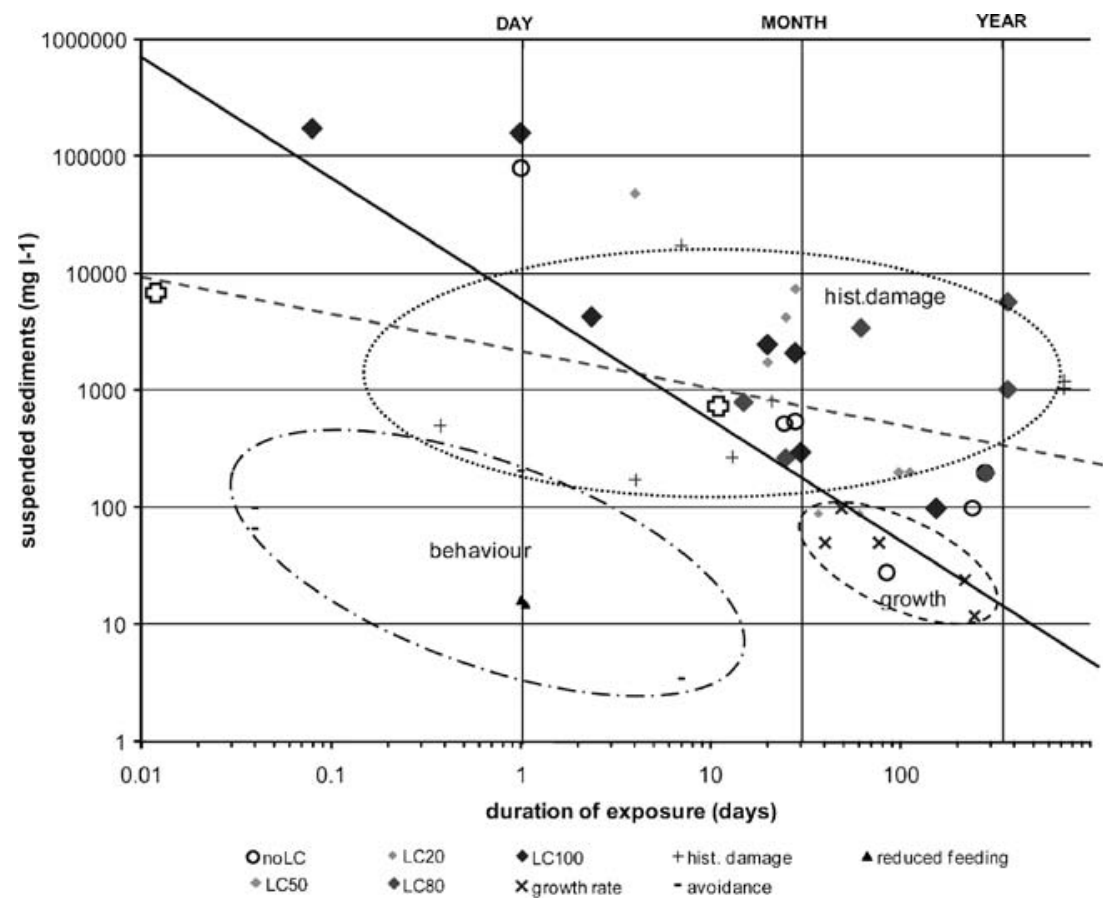

al. 2003; Newcombe and Jensen 1996). Published 96$\mathrm{h} \mathrm{LC}_{50}$ values for salmonids exposed to natural sediments are mostly above $1,700 \mathrm{mg}^{-1}$ (Berry et al. 2003; Newcombe and Jensen 1996). However, at values lower than $90 \mathrm{mg}^{-1}$ fish already show signs of sub-lethal stress (changes in blood chemistry, increased parasitic infection of gill tissue) and changes in behaviour such as reduced feeding rates, increased rates of coughing, and avoidance of turbid water with increasing risk for predation (Fig. 1; Servizi and Martens 1991, 1992; reviewed data in Berry et al. 2003; Fischnetz 2004).

The differences in the reported critical concentrations (Fig. 1) are likely related to differences in the duration of exposure and the geochemical composition and size of suspended particles (Servizi and Martens 1987 in Servizi and Martens 1992; Alabaster and Lloyd 1980; Bilotta and Brazier 2008). Different authors concluded that the duration of the exposure to a specific concentration is an important factor for possible adverse effects on brown trout (Newcombe and McDonald 1991; Berry et al. 2003; Fischnetz 2004). Moreover, the geochemical composition has to be scrutinized as it influences the angularity and particle size of the suspended particles (Servizi and Martens 1992; Alabaster and Lloyd 1980). For example, more angular particles did show effects at lower values than round particles in coho salmon (Oncorhynchus kisutch; Lake and Hinch 1999). In addition, an increase in one unit weight of silt (diameter $<0.063 \mathrm{~mm}$ ) has been found to be on average three times as detrimental to embryo survival in Atlantic salmon than a similar unit weight of sand (0.63 mm<diameter $<2 \mathrm{~mm}$; Lapointe et al. 2004).
Only limited information is available about the geochemical composition and size distribution of sediments in alpine rivers. However, measured concentrations of suspended solids in alpine rivers are below values regarded as lethal threats or are very rarely lethal during summer floods (point measurement: $<10,000 \mathrm{mg} \mathrm{l}^{-1} ;$ 14-days sample $<1,000 \mathrm{mg} \mathrm{l}^{-1} ; 80 \%$ 14-days $<300 \mathrm{mg} \mathrm{l}^{-1}$; Zobrist et al. 2004; unpublished data BWG). In Swiss lowland rivers, such lethal concentrations have not been measured and the calculated 80-percentile (14-day sample) was below $100 \mathrm{mg}^{-1}$ (Fischnetz 2004). However, these lower concentrations can affect trout health and respiration capacity (see Fig. 1) or may have negative effects in combination with other stressors, such as chemical and physical stressors. With the advance of peak-flow in spring younger life stages, more vulnerable to the exposure to suspended solids, might be affected by high loads of fine sediments because they cannot as easily evacuate to adjacent rivers like adult fish. Accordingly, studies examining type, size and shape of suspended sediments and their effects in younger life stages of salmonids are needed.

\subsubsection{Habitat requirements of gravel-spawning brown trout}

Streambeds in alpine regions naturally contain different gravel sizes, which serve as shelter and nursery for many benthic invertebrates and fish species. Brown trout (Salmo trutta) depend strongly on unimpaired gravel beds for spawning and successful egg development. Brown trout prefer to place the spawning sites (redd) in areas of shallow water ( \pm 0.2 body length, $\pm 30 \mathrm{~cm}$ in average; Armstrong et 
al. 2003; Zimmer and Power 2006) with higher water velocities (Baglinière and Maisse 2002; Zimmer and Power 2006) and the redds are usually placed at the same sites in subsequent years (Schneider 2000). For redd construction female trout excavate a depression by removing fines and gravel creating a typical pit and tail structure. Spawning fish can move gravel with a maximum gravel diameter of $10 \%$ of the fish's body length (Kondolf 2000). Moreover, egg burial depth for trout is also dependent on female size and average $15 \mathrm{~cm}(0.3-0.4$ body length; Armstrong et al. 2003). After deposition and fertilisation, eggs are covered with gravel from upstream digging during further spawning activity. After hatching, young alevin remain in the gravel until the yolk sac is used up and they emerge as 'fry' from the gravel. In case of severe riverbed clogging before spawning, eggs are either not spawned (Ortlepp and Murle 2003; Mathisen 1955 in DeVries 1997) or insufficiently covered by gravel, with an increased risk for wash out with high floods (Everest et al. 1987 in DeVries 1997). As fines are usually transported downstream by currents during redd construction, the initial percentage of fines in the redd is often reported to be lower (e.g. $-32 \% ;-41 \%<2 \mathrm{~mm}$ ) than in the surrounding substrate (Chapman 1988; Montgomery et al. 1996; Kondolf 2000, Zimmermann and Lapointe 2005). The latter ensures, together with the specific form of the redd, a sufficient exchange of water between the stream and the interstitial (Kondolf 2000), at least at the beginning of incubation (Zimmermann and Lapointe 2005). However, fine sediment infiltration into redds during the incubation period due to moderate intensity floods is likely (Zimmermann and Lapointe 2005) and redd siltation within several days has been reported (f. ex. Heywood and Walling 2007). Exposure to fine sediments during the incubation period can delay the emergence of fry, as has been shown for rainbow trout (Oncorhynchus mykiss), thereby likely altering the natural emergence pattern (Fudge et al. 2008). The deposition of fine sediment is therefore especially detrimental during the reproduction phase, including the incubation period and the time of emergence, in case of river discharge not being strong enough for downstream fine sediment transportation.

\subsubsection{Sediment deposition and riverbed clogging influencing embryo survival}

Fine sediment accumulation and gravel bed clogging can disturb interstitial flow, and subsequently oxygen supply, which is crucial for egg to fry survival (Rubin and Glimsater 1996; Rubin 1998). Critical thresholds of interstitial oxygen concentration for brown trout eggs are in the range of 7-10 $\mathrm{mg} \mathrm{l}^{-1}$ (Rubin and Glimsater 1996; Ingendahl 2001; Malcolm et al. 2003). Embryos, after hatching, are less sensitive to locally low oxygen availability, as they are more mobile (Greig et al. 2007). Under optimal gravel bed conditions with free interstitial flow and low temperatures, interstitial oxygen concentration is thought to be sufficient for embryo survival. With increasing clogging of the gravel bed by fine sediments, interstitial flow and, hence, oxygen supply is limited.

The percentage of fine sediments is often used as an indicator for reduced interstitial flow and oxygen supply and related to embryo survival and emergence success of salmonids (Chapman 1988). However, results from different studies where survival rates were correlated to percent of fines are difficult to compare and even sometimes contradicting (Chapman 1988; Greig et al. 2005a) probably also due to different thresholds for grain size of fine sediments, which had been used (Chapman 1988). As a consequence, it was suggested that other grain size-based descriptors of gravel composition (e.g. geometric mean $\left(d_{\mathrm{g}}\right)$, sorting coefficient $\left(S_{0}\right)$ and Fredle index $\left(F_{\mathrm{i}}\right.$ : index of permeability; Lotspeich and Everest 1981) might be better descriptors for survival rates $\left(d_{\mathrm{g}}\right.$ : Rubin and Glimsater 1996; $F_{\mathrm{i}}$ : Chapman 1988; $S_{0}$ : Ingendahl 2001). However, other studies found no clear relationships between these parameters and survival rates $\left(d_{\mathrm{g}}\right.$ : Chapman 1988; Rubin 1998; Ingendahl 2001; $F_{\mathrm{i}}$ : Ingendahl 2001). Neither percentage of fine sediment nor these grain size-based measures showed to be well related to survival rates in studies on Atlantic salmon (Greig et al. 2005a; Levasseur et al. 2006). Greig et al. pointed out that the processes governing oxygen flux through gravel riverbeds are much more complex, comprising a multitude of interacting factors such as organic matter, which causes a high biological oxygen demand during degradation (Greig et al. 2007). A considerable influence on oxygen supply to embryos was suggested to be due to the finest parts of sediments - silt and clay, finally affecting the survival rate (Greig et al. 2005a; Julien and Bergeron 2006; Levasseur et al. 2006). Oxygen consumption by Atlantic salmon embryos was restricted even by small quantities of clay forming a thin coating around the eggs (Greig et al. 2005a, b). This was discussed to have an influence on either reduced permeability or to direct blocking of pore canals in the egg chorion.

Although observations of fish experts and anglers indicate a general increase in riverbed clogging, it is not widely investigated and hardly any data exist on undisturbed or anthropogenically altered conditions. As measurements of gravel compositions, interstitial flow, and oxygen concentration are time intensive and raise methodological problems, a simple method for the evaluation of the riverbed clogging was developed (Schälchli method; Schälchli et al. 2002; Fischnetz 2004). However, although it is currently used for general ecomorphological assess- 
ments in Swiss rivers (Bundesamt für Umwelt 2006), a major drawback is the limitation to dry gravel banks and, accordingly, to the application to non-spawning sites and seasons.

In two consecutive years, 59 and 39 selected stream stretches in Swiss lowlands (below $800 \mathrm{~m}$ a.s.1.) were investigated for riverbed clogging with the Schälchli method (among other ecomorphological factors) and brown trout YOY-abundance (Young-of-the-Year YOY; Schager et al. 2007). In 14\% of the investigated streams, a high grade of riverbed clogging along with stream width, altitude and proliferative kidney disease (PKD) was negatively related to YOY-abundance (Schager et al. 2007). Since data on riverbed clogging were collected in summer, evidence for clogging in spawning season is restricted. The reproductive success of gravel-spawning fish was also impaired in another study investigating four selected river basins in Switzerland. Riverbed clogging (raised by the Schälchli method as well) was identified to contribute to the stated decrease in trout population size at least in some river stretches (Borsuk et al. 2006; Burkhardt-Holm and Scheurer 2007).

In another study, the reproductive success of lake trout (Salmo trutta f. lacustris) in two alpine rivers influenced by the intermittent discharge of hydropower plants was compared with two rivers with natural discharge (Eberstaller and Pinka 2001). Incubation of lake trout eggs was successful in natural rivers, whereas egg development was retarded beneath hydropower plants. The latter was discussed to be due to fine sediment deposition reducing interstitial flow and fry survival during spring floods. A high fraction of fine sediment $<0.63 \mathrm{~mm}$ was related to reduced egg development, whereas a high sediment fraction of $0.63-2 \mathrm{~mm}$ had no obvious impact.

Only limited studies on riverbed clogging and its effect on fish in the alpine region are available. Older studies do not exist and the change over time is therefore unknown. Nevertheless, riverbed clogging seems to be increasingly problematic for trout reproduction mainly in lowland streams (Borsuk et al. 2006; Burkhardt-Holm and Scheurer 2007; Schager and Peter, unpublished data).

\section{Conclusions}

An increase in climate erosive forces has been demonstrated for northern and southern Alps. High discharges increased in winter months and reach levels for gravel bed movement critical for different reproduction stages of brown trout in some lowland and pre-alpine streams north of the Alps. For alpine rivers and rivers south of the Alps data is scarce and a critical increase was not evident. In both regions, climate models also predict an advance of the peak flows in spring by $1-2$ months, which could overlap the time of advanced fry emergence.

The combination of land-use and climate change has led to increased erosion in the lowland, pre-alpine and alpine regions at least until the $1990 \mathrm{~s}$. In the Alps, the more recent development is still in discussion. Erosion has increased in some areas due to abandonment (remote regions) or use intensification (accessible regions) of land and due to climate change effects. Contrasting effects are forest regrowth in abandoned areas and further reclamation by trees of higher slopes due to climate warming. Overall effects seem to result in an increase of sediment loads in some larger river catchments and are expected to increase in future.

As high flows now also occur in autumn and winter months and earlier in spring, transport and sedimentation of fine sediment during reproduction and embryo development are expected. Strong discharges cause gravel movements, leading to egg scouring, injury and displacement of young fish. Moderate discharge events result in fine sediment infiltration into redds reducing the interstitial flow, and hence, oxygen supply, with detrimental consequences for eggs and embryos. Clay particles attached at the egg surface are supposed to impair gas exchange and reduce embryo viability, and suspended sediments affect brown trout health and behaviour depending on concentrations, but also on the size, form and quality of the particles. With the lack of long-term trend data for sediment going into rivers, sediments suspended in rivers and riverbed clogging, a direct correlation with fish population or catch data is not possible at the current state of knowledge. Recently published studies indicate a decline in trout reproduction from riverbed clogging in many rivers in lowlands and alpine regions. However, the multitude of factors in natural complex ecosystems makes it difficult to address a single causative factor. As a consequence, it has to be elucidated whether riverbed clogging and sediment concentrations present can impair fish reproduction, health and behaviour.

\section{Recommendations and perspectives}

Sediment entering rivers from erosion has been recognised by experts as a problem and several initiatives have been taken including measures to reduce these stress factors in surface water systems (Alpenkonvention 1991; Fischnetz+ 2007). These initiatives need to be implemented.

From the scientific point of view, erosion trends in the Alps are not clearly understood and further research is necessary in this field. Investigations into the consequences of climate and land-use change on river systems, such as sediment going into rivers, transport and clogging processes are therefore needed. Especially small rivers, serving as 
recruitment sites of gravel-spawning fish, are often neglected. There is also a strong need to develop methods for sound data collection on sediment input and river bed clogging. Without the latter, it will not be possible to draw consequences on scientific progress and mitigation measures. Studies on the effects of suspended sediments on fish health under environmentally realistic conditions, especially taking origin, size and shape of the particles into consideration should be carried out. Furthermore, the consequences of gravel bed clogging for reproduction of our native gravel-spawning fish, such as trout, grayling and charr are urgently needed to be studied. There is a lack of information on the linkage between riverbed clogging and interstitial gas exchange in most alpine field studies and this area should be considered in future research. In general, it is necessary to understand the abiotic-biotic interaction in aquatic ecosystems and provide suggestions for more advanced water quality guidelines (Bilotta and Brazier 2008).

Acknowledgements Thanks are due to Christian Michel for a literature update for the revised version and Geordie Colville for language clearing.

\section{References}

Acornley RM, Sear DA (1999) Sediment transport and siltation of brown trout (Salmo trutta L.) spawning gravels in chalk streams. Hydrol Process 13:447-458

Alabaster JS, Lloyd R (1980) Water quality criteria for freshwater fish. Butterworths, London, p 297

Alpenkonvention (1991) www.alpenkonvention.org

Armstrong JD, Kemp PS, Kennedy GJA, Ladle M, Milner NJ (2003) Habitat requirements of Atlantic salmon and brown trout in rivers and streams. Fish Res 62:143-170

Asselman NEM, Middelkoop H, van Dijk PM (2003) The impact of changes in climate and land use on soil erosion, transport and deposition of suspended sediment in the river Rhine. Hydrol Process 17:3225-3244

Baglinière JL, Maisse G (2002) The biology of brown trout, Salmo trutta L., in the Scorff River, Brittany: a synthesis of studies from 1972 to 1997. INRA Prod Anim 15:319-331

Baumann P, Klaus I (2003) Gewässerökologische Auswirkungen des Schwallbetriebes. Mitteilungen zur Fischerei Nr. 75. BUWAL, Bern, p 112

Bayard D, Stähli M, Parriaux A, Flühler H (2005) The influence of seasonally frozen soil on the snowmelt runoff at two Alpine sites in southern Switzerland. J Hydrol 309:66-84

Begert M, Schlegel T, Kirchhofer W (2005) Homogeneous temperature and precipitation series of Switzerland from 1864 to 2000. Int J Climatol 25:65-80

Beniston M (2006) Mountain weather and climate: a general overview and a focus on climatic change in the Alps. Hydrobiologia $562: 3-16$

Berry W, Rubinstein N, Melzia B, Hill B (2003) The biological effects of suspended and bedded sediment (SABS) in aquatic systems: a review. USEPA, Washington D.C., p 58

Beyer Portner N (1998) Erosion des bassins versant alpines suisses par ruissellement de surface. $\mathrm{PhD}$ thesis, EPFL, Lausanne, pp 230
Bilotta GS, Brazier RE (2008) Understanding the influence of suspended solids on water quality and aquatic biota. Water Res 42(12):2849-2861

Birsan MV, Molnar P, Burlando P, Pfaundler M (2005) Streamflow trends in Switzerland. J Hydrol 314:312-329

Bolliet V, Bardonnet A, Jarry M, Vignes JC, Gaudin P (2005) Does embeddedness affect growth performance in juvenile salmonids? An experimental study in brown trout, Salmo trutta L. Ecol Freshw Fish 14:289-295

Borsuk ME, Reichert P, Peter A, Schager E, Burkhardt-Holm P (2006) Assessing the decline of brown trout (Salmo trutta) in Swiss rivers using a Bayesian probability network. Ecol Modell 192:224-244

Brunetti M, Maugeri M, Nanni T, Auer I, Bohm R, Schoner W (2006) Precipitation variability and changes in the greater alpine region over the 1800-2003 period. J. Geophys. Res. [Atmos.] 111: D11107, doi:10.1029/2005JD006674

Bundesamt für Landwirtschaft (2006) Agrarbericht 2006. BLW, Bern, p 235

Bundesamt für Statistik (2001) The changing face of landuse. Landuse statistics of Switzerland. BFS, Bern, p 32

Bundesamt für Umwelt (2006) Ökomorphologie Stufe S (systembezogen). Methoden zur Untersuchung und Beurteilung der Fliessgewässer in der Schweiz (Modul-Stufen-Konzept). Entwurf. Bundesamt für Umwelt, Bern, p 72

Burkhardt-Holm P, Scheurer K (2007) Application of the weight-ofevidence approach to assess the decline of brown trout (Salmo trutta) in Swiss rivers. Aquat Sci 69(1):51-70

Burkhardt-Holm P, Peter A, Segner H (2002) Decline of fish catch in Switzerland-project fishnet: a balance between analysis and synthesis. Aquat Sci 64:36-54

Burkhardt-Holm P, Giger W, Güttinger H, Ochsenbein U, Peter A, Scheurer K, Segner H, Staub E, Suter MJF (2005) Where have all the fish gone? Env Sci Technol 39:441A-447A

Cattanéo F, Lamouroux N, Breil P, Capra H (2002) The influence of hydrological and biotic processes on brown trout (Salmo trutta) population dynamics. Can J Fish Aquat Sci 59:12-22

Chapman DW (1988) Critical-review of variables used to define effects of fines in redds of large salmonids. T Am Fish Soc 117:1-21

Crisp T (2000) Trout and salmon: ecology, conservation and rehabilitation. Blackwell, Oxford, p 212

Descroix L, Gautier E (2002) Water erosion in the southern French Alps: climatic and human mechanisms. Catena 50:53-85

DeVries P (1997) Riverine salmonid egg burial depths: review of published data and implications for scour studies. Can J Fish Aquat Sci 54:1685-1698

Diodata N, Mariani L (2007) Testing a climate erosive forcing model in the Po River Basin. Climate Res 33:195-205

Eberstaller J, Pinka P (2001) Trübung und Schwall AlpenrheinEinfluss auf Substrat, Benthos, Fische. Teilbericht Fischökologie. BOKU, Wien, p 115

EIFAC (2002) Analysis of European catch and aquaculture statistics, 1990-2000. In: European Inland Fisheries Advisory Commission, 22th session. Windermere, United Kingdom. www.fao.org/ DOCREP/MEETING/004/Y3759E/Y3759E00.HTM (accessed 07.01.2007)

FAL (2001) Evaluation der Ökomassnahmen. Phosphorbelastung der Oberflächengewässer durch Bodenerosion. FAL, Zürich-Reckenholz, p 37

Fischnetz (2004) Dem Fischrückgang auf der Spur. Schlussbericht des Projekts Netzwerk Fischrückgang Schweiz "Fischnetz". EAWAG, Bundesamt für Umwelt, Wald und Landschaft, Bern, p 178

Fischnetz + (2007) Gesunde Fische in unseren Fliessgewässern. 10Punkte-Plan. EAWAG, Bundesamt für Umwelt, Bern, p 24 
Fraser AI, Harrod TR, Haygarth PM (1999) The effect of rainfall intensity on soil erosion and particulate phosphorus transfer from arable soils. Water Sci Technol 39:41-45

Fudge TS, Wautier KG, Evans RE (2008) Effect of different levels of fine-sediment loading on the escapement success of rainbow trout fry from artificial redds. N Am J Fish Manage 28(3):758-765

Fuhrer J, Beniston M, Fischlin A, Frei C, Goyette S, Jasper K, Pfister $\mathrm{C}$ (2006) Climate risks and their impact on agriculture and forests in Switzerland. Clim Change 79:79-102

Gentile AR, Werner B (2004) Gone with the wind, gone into watersoil erosion in Europe-pressures, state and impacts. Local Land \& Soil News 10/11:6-9

Greig SM, Sear DA, Carling PA (2005a) The impact of fine sediment accumulation on the survival of incubating salmon progeny: implications for sediment management. Sci Total Environ 344:241-258

Greig SM, Sear DA, Smallman D, Carling PA (2005b) Impact of clay particles on the cutaneous exchange of oxygen across the chorion of Atlantic salmon eggs. J Fish Biol 66:1681-1691

Greig SM, Sear DA, Carling PA (2007) A review of factors influencing the availability of dissolved oxygen to incubating salmonid embryos. Hydrol Processes 21:323-334

Habersack H (1996) Lack and surplus of sediments being transported by river systems. In: Erosion and sediment yield: global and regional perspectives. IAHS 236:565-573

Hamm A, Glassmann M, Liepelt A (1996) Transport of particulate matter in an alpine river (river Salzach) and its importance for river ecology. Arch Hydrobiol 47:507-513

Hari RE, Livingstone DM, Siber R, Burkhardt-Holm P, Güttinger H (2006) Consequences of climatic change for water temperature and brown trout populations in alpine rivers and streams. Glob Change Biol 12:10-26

Herbert DWM, Alabaster JS, Dart MC, Lloyd R (1961) The effect of China-clay wastes on trout streams. Int J Air Water Pollut 5:56-74

Heywood MJT, Walling DE (2007) The sedimentation of salmonid spawning gravels in the Hampshire Avon catchment, UK: implications for the dissolved oxygen content of intragravel water and embryo survival. Hydrol Process 21:770-788

Hiltbrunner E, Paulsen J, Körner C (2005) Grazing in the high alpine and implication for slope stability. Geophys Res Abstracts 7:1607-7962, /gra/EGU05-A-08134

Horton P, Schaefli B, Mezghani A, Hingray B, Musy A (2006) Assessment of climate-change impacts on alpine discharge regimes with climate model uncertainty. Hydrol Process 20:2091-2109

Ingendahl D (2001) Dissolved oxygen concentration and emergence of sea trout fry from natural redds in tributaries of the River Rhine. J Fish Biol 58:325-341

IPCC (2007) Climate change 2007: impacts, adaptation and vulnerability. In: Parry ML, Canziani OF, Palutikof JP, van der Linden PJ, Hanson CE (eds) Contribution of working group II to the fourth assessment report of the IPCC. Cambridge University Press, Cambridge, UK, p 976

Jasper K, Calanca P, Gyalistras D, Fuhrer J (2004) Differential impacts of climate change on the hydrology of two alpine river basins. Climate Res 26:113-129

Jensen AJ, Johnsen BO (1999) The functional relationship between peak spring floods and survival and growth of juvenile Atlantic salmon (Salmo salar) and brown trout (Salmo trutta). Funct Ecol 13:778-785

Johannes B (1995) Oberflächenabfluss und Bodenabtrag bei künstlichen Starkniederschlägen von Almweideflächen im Nationalpark Berchtesgaden. Forstw Cbl 114:293-301

Julien HP, Bergeron NE (2006) Effect of fine sediment infiltration during the incubation period on Atlantic salmon (Salmo salar) embryo survival. Hydrobiologia 563:61-71
Kondolf M (2000) Assessing salmonid spawning gravel quality. T Am Fish Soc 129:262-281

Krausmann F, Haberl H, Schulz NB, Erb KH, Darge E, Gaube V (2003) Land-use change and socio-economic metabolism in Austria-Part I: driving forces of land-use change: 1950-1995. Land Use Policy 20:1-20

Lake RG, Hinch SG (1999) Acute effects of suspended sediment angularity on juvenile coho salmon (Oncorhynchus kisutch). Can J Fish Aquat Sci 56(5):862-867

Lapointe M, Eaton B, Driscoll S, Latulippe C (2000) Modeling the probability of salmonid egg packet scour due to floods. Can J Fish Aquat Sci 57:1120-1130

Lapointe MF, Bergeron NE, Bérubé F, Pouliot MA, Johnston P (2004) Interactive effects of substrate sand and silt contents, redd-scale hydraulic gradients, and interstitial velocities on egg-to-emergence survival of Atlantic salmon (Salmo salar). Can J Fish Aquat Sci 61(12):2271-2277

Laternser M, Schneebeli M (2003) Long-term snow climate trends of the Swiss Alps (1931-99). Int J Climatol 23:733-750

Lebensministerium (2003) Auswirkungen von Klimaänderungen auf die Tierwelt-derzeitiger Wissensstand, fokussiert auf den Alpenraum und Österreich. Institut für Meteorologie und Physik und BOKU, Wien, $\mathrm{p} 141$

Lenzi MA, Mao L, Comiti F (2003) Interannual variation of suspended sediment load and sediment yield in an alpine catchment. Hydrol Sci J 48:899-915

Levasseur M, Bergeron NE, Lapointe MF, Berube F (2006) Effects of silt and very fine sand dynamics in Atlantic salmon (Salmo salar) redds on embryo hatching success. Can J Fish Aquat Sci 63:1450-1459

Liébault F, Gomez B, Page M, Marden M, Peacock D, Richard D, Trotter CM (2005) Land-use change, sediment production and channel response in upland regions. River Res Applic 21:739-756

Lotspeich FB, Everest FH (1981) A new method for reporting and interpreting textural composition of spawning gravel. Res. Note PNW-369. U.S. Department of Agriculture, Forest Service, Pacific Northwest Forest and Range Experiment Station, Portland, OR, p 11

Malcolm IA, Youngson AF, Soulsby C (2003) Survival of salmonid eggs in a degraded gravel-bed stream: Effects of groundwatersurfacewater interactions. River Res Appl 19:303-316

Margreth S (2006) Partikelfluss und Sedimentbildung in Oberengadiner Seen. MSc thesis, University of Zurich, Zurich, p 56

Matulla C, Schmutz S, Melcher A, Gerersdorfer T, Haas P (2007) Assessing the impact of a downscaled climate change simulation on the fish fauna in an Inner-Alpine River. Int $\mathrm{J}$ Biometerol 52:127-137

Meusburger K, Alewell C (2008) Impacts of anthropogenic and environmental factors on the occurrence of shallow landslides in an alpine catchment (Urseren Valley, Switzerland). Nat Hazard Earth Syst Sci 8:509-520

Montgomery DR, Buffington JM, Peterson NP, Schuett-Hames D, Quinn TP (1996) Stream-bed scour, egg burial depths, and the influence of salmonid spawning on bed surface mobility and embryo survival. Can J Fish Aquat Sci 53:1061-1070

Newcombe CP, Jensen JOT (1996) Channel suspended sediment and fisheries: a synthesis for quantitative assessment of risk and impact. N Am J Fish Manage 16:693-727

Newcombe CP, MacDonald DD (1991) Effects of suspended sediments on aquatic ecosystems. N Am J Fish Manage 11:72-82

Ortlepp J, Murle U (2003) Effects of experimental flooding on brown trout (Salmo trutta fario L.): The River Spol, Swiss National Park. Aquat Sci 65:232-238

Piégay H, Walling DE, Landon N, He QP, Liébault F, Petiot R (2004) Contemporary changes in sediment yield in an alpine mountain basin due to afforestation (the upper Drome in France). Catena $55: 183-212$ 
Prasuhn V (2003) Zunahme der Bodenerosion von Ackerflächen im Winterhalbjahr? In: Mitteilungen DBG, pp 789-790

Ritzmann-Blickenstorfer H (1996) Historische Statistik der Schweiz. Chronos, Zürich, p 1221

Rubin JF (1998) Survival and emergence pattern of sea trout fry in substrata of different compositions. J Fish Biol 53:84-92

Rubin JF, Glimsater C (1996) Egg-to-fry survival of the sea trout in some streams of Gotland. J Fish Biol 48:585-606

Santschi D (2003) Zeitliche Veränderung der winterlichen Abflusscharakteristik schweizerischer Fliessgewässer. MSc thesis, University of Bern, Bern, p 109

Schager E, Peter A, Burkhardt-Holm P (2007) Status of young-of-theyear brown trout (Salmo trutta fario) in Swiss streams. Factors influencing YOY trout recruitment. Aquat Sci 69:41-50

Schälchli U, Abegg J, Hunzinger L (2002) Innere KolmationMethoden zur Erkennung und Bewertung. EAWAG, Dübendorf, p 27

Schmidli J, Frei C (2005) Trends of heavy precipitation and wet and dry spells in Switzerland during the 20th century. Int J Climatol 25:753-771

Schneider B (2000) Spawning microhabitat selection by brown trout in the Linthkanal, a mid-sized river. J Freshwater Ecol 15:181-187

Servizi JA, Martens DW (1991) Effect of temperature, season, and fish size on acute lethality of suspended sediments to coho salmon (Oncorhynchus kisutch). Can J Fish Aquat Sci 48:493-497

Servizi JA, Martens DW (1992) Sublethal responses of coho salmon (Oncorhynchus kisutch) to suspended sediments. Can J Fish Aquat Sci 49:1389-1395

Spina AP (2001) Incubation discharge and aspects of brown trout population dynamics. T Am Fish Soc 130:322-327

Stähli M, Nyberg L, Mellander PE, Jansson PE, Bishop KH (2001) Soil frost effects on soil water and runoff dynamics along a boreal transect: 2. Simulations. Hydrol Process 15:927-941

Summer W (ed) (1989) Umfassende Betrachtung der Erosions- und Sedimentationsproblematik. Wiener Mitteilungen Nr. 86, Wien

Summer W, Zhang W, Stritzinger W (1994) Consequences of human impacts on the sediment transport process. Z f Kulturtechnik und Landentwicklung 35:382-389

Summer W, Klaghofer E, Hintersteiner K (1996) Trends in soil erosion and sediment yield in the alpine basin of the Austrian Danube. In: Erosion and Sediment Yield. IAHS. 236:473-479
Tasser E, Tappeiner U (2002) Impact of land use changes on mountain vegetation. Appl Veg Sci 5:173-184

Tasser E, Mader M, Tappeiner U (2003) Effects of land use in alpine grasslands on the probability of landslides. Basic Appl Ecol $4: 271-280$

Tetzlaff D, Soulsby C, Youngson AF, Gibbins C, Bacon PJ, Malcolm IA, Langan S (2005) Variability in stream discharge and temperature: a preliminary assessment of the implications for juvenile and spawning Atlantic salmon. Hydrol Earth Syst Sci 9:193-208

Verbunt A, Zwaaftink MG, Gurtz J (2005) The hydrologic impact of land cover changes and hydropower stations in the Alpine Rhine basin. Ecol Modell 187:71-84

Walling DE (1997) The response of sediment yields to environmental change. In: Human Impact on Erosion and Sedimentation. IAHS 245:77-89

Walling DE, Collins AL, McMellin GK (2003) A reconnaissance survey of the source of interstitial fine sediment recovered from salmonid spawning gravels in England and Wales. Hydrobiologia 497:91-108

Weingartner R, Barben M, Spreafico M (2003) Floods in mountain areas - an overview based on examples from Switzerland. J Hydrol 282:10-24

Weiss FH (1996) Sediment monitoring, long-term loads, balances and management strategies in southern Bavaria. In: Erosion and sediment yield: Global and regional perspectives. IAHS 236:575-582

Wielke LM, Haimberger L, Hantel M (2004) Snow cover duration in Switzerland compared to Austria. Meteorol Z 13:13-17

Zaugg B, Stucki P, Pedroli JC, Kirchhofer A (2003) Pisces Atlas. Centre suisse de cartographie de la faune, Schweizerische Entomologische Gesellschaft, p 233

Zimmer MP, Power M (2006) Brown trout spawning habitat selection preferences and redd characteristics in the Credit River, Ontario. J Fish Biol 68:1333-1346

Zimmermann AE, Lapointe M (2005) Intergranular flow velocity through salmonid redds: Sensitivity to fines infiltration from low intensity sediment transport events. River Res Applic 21:865881

Zobrist J, Sigg L, Schönenberger U (2004) NADUF—Thematische Auswertung der Messresultate 1974-1998. Schriftenreihe Nr. 18. EAWAG, Dübendorf, p 125 